\title{
Let the People Decide! \\ Assessing the Democratic Legitimacy of the Brexit Referendum
}

\author{
Jacobus Rozenburg ${ }^{1}$
}

\begin{abstract}
While the decision to organise a Brexit has been the subject of seemingly endless debate, the legitimacy of this decision is generally accepted by those on both sides of the fence. The notion that a Brexit must happen, whatever the costs, as "the people have spoken", has cemented itself in the public debate as some form of objective truth. However, in order to safeguard British democracy, it is in fact necessary to take a more critical approach to this perceived "legitimacy". In order to provide such an approach, this paper challenges the Brexit's democratic legitimacy on two levels. First, using Canovan's "redemptive" and "pragmatic" faces of democracy, it argues that the "will of the people" has been unable to legitimise the decision to leave the EU. Second, focusing in on the conduct of the referendum, it argues that due to procedural errors, the referendum has additionally been unable to translate "the will of the people" in the first place. By taking this two-step approach to the Brexit's legitimacy question, this paper exposes the general fragile nature of referenda and highlights how the Brexit referendum has failed to communicate the "will of the people" and subsequently strengthen the UK's democratic process.
\end{abstract}

\section{Introduction}

On the 23rd of June 2016, a rough 17 million British citizens voted in favour of leaving the European Union (EU). This somewhat surprising decision pushed the British House of Commons into uncharted territory. As prime minister David Cameron abandoned ship, his honourable colleagues were left in deep uncertainty. Divided and largely clueless on how to honour the "will of the people", the British parliament pondered what to do with the outcome of this non-binding plebiscite.

Several months later, the result of the referendum was taken to heart as the United Kingdom (UK) invoked article 50 on the 29th of March 2016. However, as the passing of time would unravel, reaching consensus on the specifics of a potential Brexit was not as easy as the simplistic "yes/no" on the referendum ballot had suggested. The decision to leave the EU heavily obstructed the regular functioning of the House of Commons, and after two years of political stagnation, a clear exit strategy was still nowhere to be seen. It had become painfully clear that Brexit does not simply mean(s) Brexit. The UK parliament received a vague mandate to leave the EU but was unable to find a majority for any possible strategy of doing so. The people had spoken, but their true preferences remained unclear.

Claiming that the Brexit referendum has unchained a political crisis in the UK almost seems euphemistic. It is therefore necessary to scrutinize the decision of organising such a popular vote very carefully. This analysis does not seek to expose the referendum practice as inherently undemocratic. What it does seek to do, is challenge the words, spoken by Theresa May and echoed by countless others: "the people have spoken, we must deliver". The tendency of politicians, pundits and citizens alike to hail the referendum as the purest expression of democracy is dangerous as it completely

1 Jacob Rozenburg received a bachelor degree in European Studies at Maastricht University in 2019. At the moment he takes a Bachelor in Fine Arts at LUCA School of Arts Brussels. Contact: jacob@rozenburg.be. 
disregards the complexities of democratic rule. In order to challenge such a perception, this paper attempts to offer a more critical approach by highlighting the shortcomings of direct democracy. In doing so, it explores the constant political balancing act between popular will and constitutionalism; and engages with the question: "to what extent was the Brexit referendum democratically legitimate?". In order to provide an answer to this question, this paper identifies two assumptions on which the legitimacy of the Brexit referendum is based. First, there is the assumption that "the will of the people" is able to grant legitimacy to the decision of leaving the European Union. And second, there is the assumption that the referendum is able to communicate "the will of the people".

In exploring the accuracy of the first claim: "the will of the people is able to grant legitimacy to the decision of leaving the EU"; this paper attempts to avoid the normative discussion on how democracy ought to work, and rather attempts to describe how it does, and what the effects of the referendum are on this functioning. To do so, it uses a framework proposed by Margaret Canovan, who argues that modern democratic rule is characterised by a balancing act between two distinct but related styles of politics: redemption and pragmatism (1999). This theory is then applied to the British case, and the effects of the referendum on this balancing act are discussed. While this paper is not able to argue for the idea that the referendum is inherently undemocratic, as any theoretical discussion of democratic legitimacy is ultimately based on normative assumptions about the ideal state of democracy, it is able to expose why the reputation of direct democracy as the purest form of democracy is ultimately misguided, by highlighting how the Brexit referendum upsets the balance between pragmatism and redemption.

Moving on to the second assumption: "the referendum is able to communicate the will of the people"; this paper makes a distinction between two common understandings of "the will of the people" within the context of the referendum. The first of which being: the preference of a majority of the population with regards to a specific policy proposal. The accuracy of this interpretation of "the will of the people" being reflected by the outcome of a referendum is challenged on the basis of its conduct. The idea being that a poorly conducted referendum is unable to communicate the policy preferences of the majority of the people. Three categories are identified in which the Brexit referendum falls short of achieving proper conduct: the availability and quality of information, the clarity and accuracy of the question, and the degree of voter inclusion. The second interpretation of "the will of the people" is understood more broadly as the preference of the majority of the people with regards to politics in general. In order to challenge the accuracy of this interpretation being reflected by the outcome of the Brexit referendum, the priority problem, as theorised by Sherman Clark is put forward (1998).

\section{Categorizing the Brexit Referendum}

In order to determine the democratic legitimacy of a referendum, it is important to first define its nature and use. As referenda come in many different shapes and forms, this section provides a brief specification of the variety of referendum used in the case of the Brexit vote. While the specifics of the voting procedure will be addressed later in the analysis, this first section only describes the general nature of the referendum. Namely, a constitutional referendum which was legally merely advisory, but had a binding practical and political nature.

While the UK does not have its own codified constitution, it is not inaccurate to state that the Brexit referendum had a highly constitutional nature (Paun, 2016). This is the case as the various legal documents, including statute law, parliamentary conventions and common law; which function as the 
British Constitution, need to be altered as a result of the Brexit vote. While the British Parliament does in fact hold the legal competences to alter the "constitution", it is commonly believed that such constitutional amendments need to be legitimised through a referendum as no ruling government should have the power to reform the character of the state without specific consent of the people (Paun, 2016). This means that in practice, the UK government usually organises referenda prior to constitutional changes. This was the case for the UK's EEC membership referendum in 1975, the UK's electoral reform referendum in 2011 and as we established, the EU membership referendum in 2016. It must be noted that although this premise is where the Brexit referendum derives its democratic legitimacy from, the decision to organise an EU membership referendum was not necessarily supported by the same motivation. In practice, it can be said that David Cameron called for a referendum to convert UKIP voters ahead of the general elections, and simultaneously close a political rift within his own conservative party (it was widely believed that "remain" would win).

Although the UK government generally organises a referendum before making constitutional changes, the results of such referenda are never legally binding as the British parliament ultimately retains the highest sovereignty (Raitio \& Raulus, 2017, p. 29). This was also the case for the Brexit referendum. In theory, it was merely an advisory referendum. However, in practice, it is very unlikely for a ruling government to ignore the population on such an important constitutional issue (Raitio \& Raulus, 2017, p.29). The insistence of David Cameron and his conservative party on honouring the results of the referendum, meant that ignoring the "will of the people" would be disastrous for the popularity of the party (The Conservative Party, 2015, p. 73). This is especially true when considering the highly competitive "two and a half party" system which characterizes British politics. In short, it can thus be said that the 2016 referendum on EU membership was a politically binding constitutional referendum. The referendum derives its democratic legitimacy from the notion that is able gauge public opinion prior to passing legislation which would dramatically alter the legal foundation on which the UK's political system was built (Paun, 2016). We can thus conclude that the Brexit referendum was an attempt at measuring the "will of the people" by establishing the preferences of the majority of citizens eligible to vote. This "will of the people" was subsequently used to legitimise the decision to leave the European Union.

As the referendum had a politically binding nature, it can be assumed that those who called for it (David Cameron and the Conservative party), and those who implemented it (Theresa May and the Conservative party), adhere to an interpretation of democracy in which majority rule is democratically legitimate. If this weren't the case, calling for a Brexit referendum and subsequently implementing the outcome, would not be logical. Additionally, it is safe to assume that those who called for and implemented the Brexit referendum, supposed that the outcome of the vote would reflect the "will" of the majority of the population. If this weren't the case, implementing the results would be illogical as even the logical underpinnings of majority rule would be harmed. This means that those who took or supported the decision to subject Britain's EU membership to a popular vote, did so based on two very important but ultimately disputed interpretations about the nature of democracy and democratic procedures. For the Brexit referendum to be accepted as legitimate, these two core assumptions must be accepted. First, one must accept that the referendum is able to reflect "the will of the people" and second, one must accept that the "will of the people" is able to grant democratic legitimacy to government action. Without embracing these two assumptions, it is difficult to interpret the referendum 
as the pinnacle of democratic expression. Therefore, the next part of this analysis makes an attempt at demonstrating why crude popular power is not able to strengthen the quality of British democracy, while the second part highlights why the requirements for the accurate communication of popular power are not met in the first place.

\section{The will of the people!}

For the sake of clarity, the first part of this discussion assumes that the result of the referendum mirrors the preferences of the majority of the British population. Making such an assumption allows us to separate the discussion on the conduct of the referendum from the discussion on the legitimacy of raw popular power. Starting with the latter, this section discusses the question: "is popular power able to grant democratic legitimacy to the decision of leaving the EU?".

Unfortunately, as there is no clear-cut uncontested definition of democracy, there is also no uncontested definition of democratic legitimacy. Generally, we can only say that democratic legitimacy is the ability of a democratic system to fulfil the requirements determined by a specific democratic ideal. While there is certain general overlap, such interpretations still differ widely and assessing democratic legitimacy therefore ultimately becomes a normative discussion. In order to overcome this hurdle, this paper discusses the democratic legitimacy of popular power within the context of the British system. Instead of determining an ideal type of democracy and testing the implications of the Brexit vote against its ideals, this first section does not focus on how democracy 'should' work, but rather on how it 'does', and subsequently, how the use of referenda affects this functioning. Both as a corrective, and as a threat.

\subsection{Two faces of democracy}

To describe the state of democracy and determine the place which the referendum is able to occupy within it, we turn to the work of Margaret Canovan. Drawing on Oakeshott's differentiation between the "politics of faith" and the "politics of scepticism", Canovan argues that modern democracies are characterised by two contrasting styles, or "faces of politics" (Oakeshott \& Fuller, 1996) (Canovan, 1999, p.8). These two faces of politics are "redemptive politics" on the one hand, and "pragmatic politics" on the other (p. 9). The redemptive face of politics as identified by Canovan is characterised by the idea that democratic rule must be a reflection of popular power. Redemptive politics promise salvation, direct spontaneous political power and a government of, by and for the people (p. 10). In stark contrast, the pragmatic face of politics is characterised by high levels of institutionalisation, limited popular power and a less ambitious take on the role of government (p. 10). Pragmatic politics serves to avoid conflict and ensure well-being, not to promise salvation (p. 10).

Modern democracies exhibit both of these two faces. They are built on notions of popular power, salvation through politics and romanticised spontaneous rule, but they are also engrained in the realities of modern societies (p. 10). Democracies need institutions to constitute, guide and limit political power (p. 10). They need the rule of law to preserve peace and stability, and they need political expertise to be able to co-exist in a complex international setting (p. 10). While these two faces of democracy are contrasting in nature, they are both necessary in order to ensure the proper functioning of modern democratic systems (Canovan, 1997, p.16). A system based purely on the redemptive style of politics quickly devolves into a "tyranny of the majority" while at the same time never being able to fully satisfy its quest for salvation due to the complicated and interrelated nature of exercising political rule in a

\footnotetext{
$4 \begin{aligned} & \text { Marble } \\ & \text { Research } \\ & \text { Papers }\end{aligned}$
} 
globalised world (p.12). A purely pragmatic system is also undesirable, because democracy is ultimately a system based on the concept of self-rule. A certain degree of redemption must thus be present at all times in order to steer and legitimise the exercise of political power. Without a promise of redemption, contestation and accountability suffer, and governments run the risk of losing the approval and legitimacy to exert political power, often leading to political stagnation and corruption (p.11).

Both faces of democracy are thus crucial for a properly functioning government and retaining the right balance between them is of utmost importance. In order to assess whether the Brexit referendum constitutes a threat or a corrective to British democracy, it is thus necessary to place British democracy in the framework devised by Canovan, and subsequently assess the impact of the referendum on its internal balance between redemptive and pragmatic politics.

\subsection{British democracy}

In 1996, Denis Balsom described the UK as "the most pragmatic of political cultures (Gallagher \& Uleri, 1996, p. 209). It is no coincidence that UK politics have long been characterised by a strong emphasis on representative rule rather than spontaneous direct rule. Eighteenth century MP, Edmund Burke, perfectly exemplified this tradition when he told his electorate: "your representative owes you not his industry alone but his judgement; and he betrays, instead of serving, you if he sacrifices it to your opinion" (p.209). Officially, this sentiment is still present in contemporary UK politics. Although the UK does not have a codified constitution, convention still dictates that absolute sovereignty lies with the Crown in parliament, not with the people (p.209).

However, in the years leading up to the Brexit referendum, this seems to have changed in the day to day practices of UK politics. In direct contradiction with her own, and the majority of her colleagues', personal judgments, Theresa May felt obligated to trigger article 50 and guide the UK out of the European Union. With the motivation for doing so being the notion that "the people had spoken". As she triggered article 50, Theresa May perfectly illustrated the shift in the British attitude towards governance. From a system in which absolute sovereignty lies with the parliament, to a system where a narrow popular majority is able to force constitutional change upon the government.

In order to understand this shift, we must first delve a bit deeper into the characteristics of British democratic rule. Although the UK currently has a clear pragmatic face represented by high levels of institutionalization and a reliance on the rule of law (Gallagher, 2007, p. 63), it also possesses characteristics which emphasise a redemptive style of politics. The British emphasis on majoritarianism which manifests itself in a 'first past the post' voting system (FPTP), highly competitive 'two and a half party' parliament and a 'talking' rather than 'working' parliamentary assembly (Gallagher, 2007, p. 63), are all highly effective in evoking a need for political redemption among citizens. Due to constant party competition, British politics put much more emphasis on theatrics and drama (p. 63). Promises of salvation are made, and both the Conservative and Labour parties are characterised by high levels of 'people-centrism' (March, 2017, p.289). The House of Commons is a theatre for heated political debate where MP's are assigned based on their rhetorical skills rather than their policy expertise (Gallagher, 2007, p. 63).

Where most Western-European democracies, including the supranational European Parliament (EP), strive for consensus, the British system does not (Gallagher, 2007, p.63). The British House of Commons can be described as a highly competitive legislature based on a majoritarian interpretation of 
politics. Due to FPTP voting, political power is vested in a small number of parties, most notably the Conservative and Labour parties. When one of these parties is able to secure a majority of parliamentary seats, either on its own or with the help of a second minor party, they are subsequently awarded a claim to power which goes largely unchecked by the opposition parties. The opposition parties are able to critique the government in an attempt to gain voters in upcoming elections, but they are unable to truly influence the functioning of the government (p. 63).

These characteristics evoke an urge for political redemption with voters, as the main organ of the British government, the House of Commons, presents itself in a more emotional and less professional style than most other Western-European parliaments. It does not strive for pragmatic compromise, but focusses on conflict, majoritarianism and promises of redemption. However, this redemptive style has historically been mostly a façade for relatively pragmatic proceedings. For example, while UK politics have used the EU as a scapegoat for all manner of problems for nearly fifty years, no UK parliament has ever decided to leave the union. In general, they always largely continued to pragmatically cooperate with it. This way of proceeding finally resulted in an electorate which no longer trusted the judgement of their representatives and longed for political salvation.

The gap between the pragmatic realities of UK politics, and the redemptive promises thrown around in the House of Commons ultimately resulted in the calling for a Brexit referendum. In order to describe this process in more detail, Canovan's explanation of how populist movements arise must be discussed as this process closely resembles the one which led to the Brexit referendum. The following section argues that the traditional pragmatic political structures of the UK combined with the highly redemptive nature of UK political practice are able to explain the thirst for direct democracy among the British electorate.

\subsection{The populist remedy}

Canovan argues that populist movements are able to flourish in the gap which exists between the pragmatic and redemptive faces of democracy $(1999$, p.9). This is the case as populists are able to exploit the existing frictions between pragmatism and redemption. It can be said that populists strengthen the redemptive side of politics by criticizing the practical limitations of democratic rule. The inability of democratic systems to give citizens the power to true self-rule, which is caused largely by logistical and practical factors, is used by populists to amass a following ( $p$. 12). They do so by proposing an alternative approach to politics, which promises to give the power to the people. Populists denounce institutions, praise direct rule and are able to critique the often unambitious and uninspired realities of modern-day politics by promising the population an alternative and simplified road towards political redemption. Unfortunately, these promises are usually in direct conflict with the practical limitations of ruling at a mass scale, and in an international setting.

This same categorisation can be applied to the Brexit referendum. The Brexit referendum is a redemptive tool as it not only challenges the constitutional and political status quo, but as it does so based on a simplified promise of redemption which is difficult to carry out in practice. For the sake of the referendum, the EU is presented as the summum of pragmatic politics. Far-removed, highly institutionalised and highly technical. Breaking with the European Union therefore liberates the UK and leads to the salvation of British Politics. It is a very simple and highly redemptive solution to a complex set of political problems. 
In this sense, it can be argued that the need for a referendum arose from the same conditions that allow populists to amass power. It is therefore also no coincidence that the referendum was initially propagated by the populist UK Independence Party (UKIP), and that it was organised only as David Cameron promised to do so in an attempt at converting UKIP votes ahead of the 2015 general elections (Smith, 2016, p.7). Just like populism advocates, the referendum was designed to renew politics by channelling the "will of the people", circumventing complex institutional structures and proposing simple solutions to complex problems. The fact that the British FPTP system makes it so difficult for smaller (populist) parties to break through into mainstream politics is an important reason why there was so much support for a referendum. The release mechanism for political frustration which is usually provided by populist parties is largely lacking in the UK. This has resulted in high levels of populist sentiments within established parties (March, 2017), but also in a thirst for alternative and more direct ways of influencing politics.

In short, it can be said that the Brexit referendum came about because the British style of politics preaches redemption, but generally exercises pragmatism. This contrast is usually exploited by populist parties which advocate for a new and better way of practicing politics which promise political salvation. However, as the British system does not easily allow for small parties to gain access to parliament and is generally unable to seek compromise when they do, the redemptive itch went largely unscratched. Within this context the referendum was proposed, to provide the redemptive tools which the population longed for. The fact that the referendum fulfils a similar role to populist movements does not mean it is democratically illegitimate, as populism itself is also not necessarily democratically illegitimate. It does however mean it has a specific impact on the balance between pragmatism and redemption, pushing British democracy further into the redemptive corner. This fact can be perceived as both a threat or a corrective to democracy (Kaltwasser, 2012, p. 184). This depends mostly on how one believes democracy should ideally function (p. 185). As British politics is based on two distinct styles of democracy, pragmatism and redemption, it is thus necessary to see how the referendum affects these.

\subsection{Appraisal and Criticism}

Before assessing the effect of the Brexit referendum on the British balance between redemption and pragmatism, a few common arguments in favour and against the use of referenda must be presented. Those in favour of referenda commonly argue that the referendum is the most direct, and therefore the purest form of democracy. It is free from institutional distortions and puts political power directly in the hands of the people. This means that it is inherently democratic and is able to grant true legitimacy to government policy. Furthermore, it is a great tool to criticize the ruling class and highlight mass dissatisfaction. Common arguments against the use of referenda usually involve the notion that direct democracy leads to a tyranny of the majority. This is the case as referenda undermine the sovereignty of the parliament and the institutional mechanics which are able to protect minority interests through political bargaining and compromise. Additionally, referenda lack the ongoing accountability of representative democracy. Once a decision is made, it is difficult to overturn.

In essence, these core sentiments can be divided into two opposing camps. Those who stress popular sovereignty over institutional protection, and those who stress institutional protection over popular sovereignty. In this way, it can be said that these two camps are rooted in Canovan's two 
opposing styles of democracy. This means that the answer to the question: "is popular power able to grant democratic legitimacy to leaving the EU"; is highly dependent on whether one favours redemption over pragmatism, or the opposite. However, the next section offers an alternative approach which does not favour one interpretation over the other, but rather argues that even if one favours a redemptive approach to politics, the Brexit referendum is in fact unable to strengthen the redemptive face of British Democracy. While the referendum is designed to increase the citizens ability to self-rule, it achieves the exact opposite.

\subsection{Taking back control}

Take back control (Vote Leave, 2016)! This mantra clearly demonstrates that the decision to leave the EU was above all a matter of British citizens wanting to increase their own control over political proceedings. It was mainly inspired by anti-elitist sentiments (Iakhnis, Rathbun, Reifler \& Scotto, 2018, p.5). Unsurprisingly, the most common motivation given for voting leave by UK citizens was "Decisions about the UK should be taken in the UK" (Ashcroft, 2016). This sentiment is arguably deeply redemptive in nature. It emphasizes direct spontaneous popular rule without the interference of far removed institutions such as the EU. Although the EU has been proclaimed as the cause of a large variety of British issues, both deserved and undeserved, the vote to leave the EU was ultimately mostly a question about self-determination. The Brits should be in control of their own borders, they should be in control of their own laws, and they should be in control of their own money (Vote Leave, 2016).

If we take this to be the aim of the British electorate, the mere organisation of a Brexit referendum does partly satisfy this hunger for more intense popular political influence. The referendum initially succeeded in appeasing the need for redemptive and direct politics, and in doing so, it partly closed the gap between pragmatism and redemption. This is clearly a positive outcome as this gap is a source of a great deal of political anger. Unfortunately, this referendum solution does not take into account the inherently contrasting nature of democracy. The gap between political salvation and the pragmatic realities of British rule have long been blamed on the EU. Economic problems are argued to be caused by the instability of the Eurozone, concerns over immigration are said to be the result of the EU's migration policies and ultimately, the lack of redemption in UK politics is portrayed as the product of EU interference. Such framing quickly leads to the assumption that leaving the European Union will allow British people to take back control over their own destiny and seek political salvation.

However, this assumption is false. Political frustration in the UK is not caused by political interference by the European Union but emerges as a result of the nature of democracy. Just as Canovan argues that populism "follows democracy like a shadow" (1999, p. 10), the gap between the redemptive expectations of citizens and the pragmatic realities of democratic rule will never cease to exist. Leaving the EU will not and cannot provide the level of redemption that citizens long for. Democratic governments are never able to truly ensure economic and social well-being (Canovan, 1999, p.12). Although citizens will naturally expect the government to look after their interests, and politicians naturally promise to do so, the ability of politicians to keep this promise is ultimately subjected to many external factors (p. 12). Because of this, the gap between redemptive promises and pragmatic realities will always remain. Especially in the UK where FPTP voting, an inability to strive for consensus and a "talking" rather than "working" parliamentary assembly ensure that this gap is much larger than it is in most other European democracies.

\footnotetext{
Marble

8 Research Papers
} 
In fact, it can be argued that the political anger which breeds in this gap will only worsen as a result of the referendum. The referendum has brought salvation within reaching distance, but it will never be able to deliver it. By allowing the electorate to opt for a redemptive catch-all solution to all their problems, the UK government has shot itself in the foot. The British people rightfully expect their government to deliver on their promise, and the House of Commons inability to deliver this promise has caused a great deal of additional frustration, both among leave and remain voters.

The fact that leaving the European Union will do nothing to increase the average UK voters' degree of political influence will further complicate matters. The degree to which, "the people rule" will not increase in British politics. At least not as a direct result of the referendum. The harsh realities of political and economic interdependence within a globalised world, in which international politics are ultimately based in anarchy, ensure that the UK will not suddenly enjoy the absolute capacity to selfrule. In the bigger picture, being part of the EU ultimately only increased the British citizens capacity for direct self-determination by giving them a seat at the negotiation table of an internationally relevant political body.

\subsection{Redemptive legitimacy}

Answering the previously posed question: "is popular power able to grant democratic legitimacy to the decision of leaving the EU?", remains difficult due to the fact that democratic legitimacy is a disputed concept. However, as this paper attempts to assess democratic legitimacy not on the basis of how democracy ought to work, but on Canovan's account of how democracy does work, democratic legitimacy can be understood as the ability of a democratic measure to ensure a balance between pragmatism and redemption. As Canovan argued, neither of these two styles of politics are able to exist without the other, and it is thus important to retain a certain degree of pragmatism and redemption in any democracy at all times. In this context, the democratic legitimacy of the Brexit referendum is thus derived from its ability to strengthen the redemptive face of British politics.

Unfortunately, the subject of the referendum, paired with the nature of democracy ensure that ultimately, the referendum has heightened political anger without providing British citizens more control over politics. This shows that the referendum is in this sense not democratically legitimate, as it destabilizes British democracy instead of balancing it. The inability of the British parliament to strive for any compromise or consensus highlights the true barrier to better representation and political determination in the UK. Perhaps, the Brexit crisis will act as a vehicle for future democratic reforms in the UK which will be able to appease political frustration, but in the short term, the referendum has not been a positive influence on the internal balance of British politics. This means that the outcome of the referendum is in conflict with the pragmatic concerns over the use of referenda, by undermining institutional protection, but it is also in direct conflict with the ideals of those who advocate for redemptive politics, as the referendum has increased political anger but has been unable to provide a release for this anger. Due to the nature of democracy, this release will never occur, and the redemptive qualities of the UK are thus not strengthened either.

While the referendum as a political tool can be used to strengthen the redemptive face of democracy, and can thus be democratically legitimate according to a democratic ideal which emphasises such values, its use should remain limited to questions which are not in direct conflict with their own aims and with the nature of democratic rule. Deciding when a referendum can be used to increase the 
political power of citizens, instead of only heightening frustration, is thus of vital importance. The timing and circumstances of a referendum are crucial in determining its democratic legitimacy. This means that while it is impossible to denounce the referendum as inherently undemocratic, the opposite is just as true. Many different factors are capable of influencing the ability of a referendum to strengthen the democratic process. These include the ones stressed above but are not limited to them. In order to explore the additional factors which are of importance in determining the democratic legitimacy of any referendum, the second part of this analysis goes a step further, and poses that, even if the timing and use of a referendum ensure its ability to strengthen democracy (which is not the case for the Brexit referendum), the referendum is still not always able to reflect "the will of the people".

\section{The Will of the People?}

It could be argued that the Brexit referendum will ultimately be able to strengthen political redemption by acting as a kind of sledgehammer, which is able to break open the system, and lead to future democratic reforms which will in fact strengthen political self-determination. However, such an interpretation is still dependent on the ability of the referendum to reflect the populations demand for more political redemption. This ability must therefore be challenged too.

The concept of "popular will", which is summoned by proponents of direct democracy, as the legitimising factor for the use of referenda, is highly elusive. In the case of the referendum, this concept can be separated into two distinct forms. First, in more pragmatic terms, popular will within the referendum practice can be understood as the preference of the majority of the people with regards to a specific policy goal (in this case leaving the EU). Second, popular will can also be understood as the ability of the majority of the people to communicate their political preferences through a direct vote. While these concepts might appear similar, they are nonetheless distinct in nature.

The ability of the Brexit referendum to reflect this first interpretation of popular will, the preference of the majority with regards to specific policy outcome, relies mostly on the quality of its conduct. A well-executed referendum can reflect the policy preference of the majority of the people. Unfortunately, in the case of the Brexit referendum, there are certain obstacle to accurate representation. Concretely, three categories where the conduct of the Brexit referendum displayed significant shortcomings are identified. These three categories are: the availability and quality of information, the clarity and accuracy of the question, and the degree of voter inclusion. The ability of the Brexit referendum to translate the second interpretation of popular will, the political preferences of the majority of the people, remains more difficult, even when the referendum were to be executed perfectly. Due to the interrelated nature of all policy goals and the inherent priority problem which haunts the referendum, it is not easy to argue that a popular vote is able to clearly communicate the actual political ideals held by the majority of the population. This is a problem which characterizes most forms of plebiscitarian procedures, including the Brexit referendum.

\subsection{An informed electorate?}

With regards to the ability of the Brexit referendum to reflect the policy preference of the majority of the British people, the electorate needs to have access to complete and correct information. The ability of any democratic procedure to produce effective and constructive policy outcomes ultimately relies on the level of insight held by those who are in charge of providing the mandate for political action. As in a 
democracy, this task is reserved for the electorate wherefore it is of vital importance that they have access to sufficient information and are able to make an informed decision.

This is also the case for the Brexit referendum. While misinformation is a problem for any democratic procedure, it is especially damaging to a referendum as it is a one-off decision which lacks the ongoing accountability present in regular elections (Kröger 2019, p.8). The referendum campaign thus deserves an even higher level of scrutiny. The Brexit campaign was plagued by many lies and partial truths, most notably from the leave side. Although it is always difficult to determine the exact extent of the effect of such misinformation on the outcome of the referendum, its impact remains certain. When looking at the website of the "Vote Leave" campaign, which was designated as the official campaign in favour of leaving the EU by the UK electoral commission, it becomes clear that many of the core arguments employed in the leave campaign were highly misleading. Examples of these include, the infamous "350 million pounds a week to the NHS" claim, which was made not only by the vote leave campaign but supported among others by UK foreign secretary Boris Johnson ("Why Vote Leave", 2016). This claim was misleading not only as such a promise could not be made, but also as these figures did not correspond to reality in the slightest. When taking into account the UK rebate (100 million pounds weekly) and the direct four billion pounds of EU investments into the UK annually, the weekly sum paid sits closer to 170 million pounds per week (UK Statistics Authority, 2019). Furthermore, this figure does not even consider the extra economic activity generated by the UK's access to the single market. The promise that leaving the EU will allow the UK to invest 350 million additional pounds weekly into the NHS is thus highly misleading and objectively falsifiable.

Another example of a false argument employed by the "Vote Leave" campaign was the claim that Turkey was on the brink of joining the European Union, leading to 76 million new possible migrants flowing into the UK, and a new EU border with Syria and Iraq ("Why Vote Leave", 2016). While it is true that Turkey has been an EU candidate since 1999, it has currently only been able to provisionally close one out 16 membership negotiation chapters, which means that Turkish accession is not going to occur in the near future (European Commission, 2019). Additionally, the EP voted to suspend the accession talks with Turkey in March of 2019, reiterating the unlikelihood of Turkish EU membership without the introduction of radical reforms.

While these are just two examples, they are part of a far greater body of lies and partial truths employed by the leave campaigns. Furthermore, the remain camp also employed false facts in order to sway voters. For example, the official remain campaign "Britain Stronger in the EU" was found guilty of using unverified numbers in supporting their arguments that Britain's economy would suffer from a potential Brexit (Kröger 2019, p.8). In addition to the spread of false information by politicians and official campaigns, the availability of accurate information was also harmed by instances of fraud. For example, the leave campaign was found guilty by the electoral commission of breaking electoral law by exceeding official spending limits which led to higher exposure (Kröger 2019, p.7). A second instance of fraud came in the form of the Cambridge Analytica scandal, when it came to light that "Leave.EU" had hired companies to run targeted ads on social media, based on illegally obtained user information (Kröger 2019, p.7).

The circulation of entirely and partially false claims on the results of leaving the EU, and the instances of campaign fraud have undermined the citizens ability to inform themselves. While, as Bellamy claims, such practices also regularly occur during general elections (2018, p.129), they are even 
more dangerous to the conduct of a referendum due to its unaccountable nature. Unlike politicians elected during general elections, the outcome of a referendum can not simply be voted out of office after four years of poor performance. The kind of ongoing accountability which is incorporated into most representative democratic systems is sorely lacking in the case of a referendum. This therefore exposes not only a first limitation of the referendum's ability to reflect the will of the people, but also the generally vulnerable nature of the referendum. As a result of misinformation, many people's expectations of leaving the EU will not come to fruition. However, this is also caused by a second shortcoming of the referendum: the phrasing of the Brexit question.

\subsection{A clear question}

At first glance, the question to leave or not to leave the EU seems fairly clear. However, upon exploring what either of the choices on the ballot, specifically the leave option, entail exactly, things become problematic. As the House of Commons has come to accept over the last years, Brexit does not simply mean Brexit. In fact, Brexit can mean a wide variety of highly divergent scenarios which all have vastly different outcomes. As the Brexit referendum only gave the electorate the choice between leaving and not leaving the EU, it fell short in truly testing the preferences of the British people.

As argued by Sandra Kröger, voters had many different reasons for voting leave, of which, many were incompatible with each other (2019, p. 6). The abstract nature of the question "allowed hard and soft 'Brexiteers', market fundamentalists and protectionists, open-door internationalists and xenophobes all to add their votes together, creating a coalition of incompatible voters (Kröger, 2019, p.6). While the remain side had to vow for a fairly clear scenario, namely, that of the status quo, the ambiguous nature of the leave option allowed those campaigning to leave the EU to do so on many different and ultimately incompatible grounds, attracting a wide variety of different voters. Ultimately, this ended in an unclear mandate for the UK parliament, and a vast number of disappointed voters, as even those on the winning side are likely to be unhappy with the specific shape Brexit will take. Additionally, due to the binary nature of the referendum, any intermediate or alternative solutions were dismissed in advance (Offe, 2017, p.19). By offering only one radical alternative to the status quo, the Brexit referendum simplified the solutions to any existing societal problems to such an extent that it removed any possibility for "postvoting reasoning and compromise finding in the institutional framework of representative democracy" (p.19). This is harmful as it essentially limits the capabilities of the British parliament in finding a constructive intermediate solution that is to the liking of the largest possible group of British citizens.

While it is always difficult to predict the outcome of a highly complex constitutional change such as leaving the European Union, it is especially difficult to do so if one does not know what this change will entail exactly. Without knowing whether leaving the EU entails a Norway plus scenario, whether it follows the swiss model, the Canadian model or results in a no deal Brexit, it is impossible to make an informed decision. Especially when taking into account the high level of division among British MP's and the many shortcomings of the referendum campaigns.

\subsection{A well-defined franchise}

A third requirement that must be fulfilled if a referendum wants to reflect the preferences of a majority of the people, is universal suffrage. Unfortunately, it can be argued that the Brexit referendum falls

\footnotetext{
$12 \mid$\begin{tabular}{l|l} 
Marble \\
Research \\
Papers
\end{tabular}
} 
short in this respect too. The Brexit referendum did not allow certain groups to vote, even though these groups had high stakes in the matter.

First, EU citizens, who resided and paid taxes in the UK, were excluded from casting their vote in the referendum (Kröger, 2019, p.5). This meant that 2.15 million votes, which would most likely have been cast in favour of remaining in the EU, were not considered in the final outcome. This is highly relevant as the Brexit referendum was won by a margin of only 1.5 million votes. While this rule also applies in general elections, there are definite arguments in favour of revision in the specific case of the Brexit referendum. As this excluded group of citizens is most vulnerable to, and most affected by the outcome of the referendum, it is undemocratic to refuse them an opportunity to vote (Offe, 2017, p.19). When taking into account the fact that Irish and Commonwealth citizens were able to cast their votes in the referendum (Gov.UK, 2019), the exclusion of EU citizens seems even less logical. Furthermore, over 700.000 British nationals who had been living abroad for more than 15 years were also denied the right to vote, even though they possessed British passports (Gov.UK, 2019). This group was also more likely to vote in favour of remain as they relied on British EU membership to reside in other EU member states. A third and last group which was arguably underrepresented in the referendum were young voters.

Upon studying the turnout rates of the Brexit referendum, it becomes clear that there was a strong relation between age and turnout, with older citizens being more likely to vote (Burn-Murdoch, 2016). While this is ultimately a matter of personal responsibility, it is nevertheless harmful to the legitimacy of such a popular vote when many those who are affected most by the outcome refrain from voting. Such an imbalance severely harms the democratic egalitarianism of the referendum (Offe, 2017, p.20). In addition, sixteen and seventeen year olds were also excluded from voting. While this is standard procedure for general elections in the UK, one could argue that the definitive and irreversible nature of the referendum require the electorate to be defined more generously. Such was also the case for the Scottish independence referendum of 2014 where the age threshold was reduced from eighteen to sixteen.

Sandra Kröger argues that in the case of the Brexit, there were two core reasons that the franchise was defined in such a limited way (2019, p.6). First, during the process of negotiating the franchise, a House of Commons briefing paper reiterated the fact that the referendum would not be binding on parliament or government, even though in practice, it had a binding political nature (p.6). And second, the Brexit faction of the conservative party was allowed to limit the franchise, as at the time, it was thought that remain would win regardless of these limitations (p.6).

\subsection{The priority problem}

With regards to the second interpretation of popular will, the three aforementioned categories are relevant, but even in a situation where they are executed properly, the referendum still inherently obstructs the possibility of communicating the "will of the people". The second interpretation of popular will is one which is more commonly understood when politicians refer to the "voice of the people". It refers to the general political preferences of the majority of citizens. As no one is able to secure their own ideal political outcome in any given situation, citizens decide for themselves what they most want to achieve/change, and what they are willing to give up in return (Clark, 1998, p.448). This means that while one might be in favour of policy proposal A, one might care so much about securing policy 
proposal $B$, that one is willing to decline proposal $A$ to get $B$ in return. While one might thus belong to the majority in favour of policy proposal A, one's true political preference is that one is largely indifferent towards proposal A when compared to proposal B.

Essentially, the difference between the first and second interpretations of popular will as proposed earlier, relate to a democratic priority problem. Elaborated by Sherman Clark, in his Populist Critique of Direct Democracy, the priority problem describes a scenario in which democratic voting disregards the intensity of the impact the outcome of a vote has on different citizens (1998, p.451). Even though certain citizens have more to lose, and therefore have stronger preferences with regards to the outcome of the vote, in a referendum, there is no mechanism to account for this difference (p.451). While one voter might opt for leave as they prefer the British blue passport covers over the European red ones, another might vote remain as their livelihood depends on access to the single market. Or alternatively, while one person might vote remain as they enjoy having no data surcharge on their yearly trip to Spain, another might vote leave as they need the government to invest 350 million extra pounds into the NHS in order to cover the treatment of their life threatening illness. While at first glance this might seem like a utilitarian problem, Clark argues that it is not (p. 437).

As no policy proposal stands on its own, it is dangerous to conduct separate binding votes on them. By isolating policy questions into separate votes, the true political preferences of citizens are obscured as they are no longer able to communicate the intensity with which they want to achieve a certain outcome with regards to their other political preferences (p.451). This can lead to a situation where a relatively apathetic majority prevails over a minority which has a great deal to lose in the matter (p. 450).

If a majority of well-informed citizens votes yes to proposition A, this does not necessarily mean that this majority prefers a world in which this proposition is enacted (p.451). This is the case as in a diverse society not everyone can get what they want all the time, and when we take into account that any possible proposition is just a part of a wider set of propositions, citizens might want to give precedence to another proposition over proposition A. Unfortunately, a referendum can never provide the citizen with the opportunity to communicate this preference. For example, someone might vote to leave the EU as they feel patriotic and believe that British sovereignty is more important than European cooperation. However, as these sentiments are not particularly important to them, they would be willing to remain in the European Union if they could secure better healthcare in return. This type of political bargaining which is a key mode of operation of most representative democracies is therefore completely disregarded by the referendum, and therefore distorts the "will of the people" (p.457). Such bargaining occurs in parliaments through processes such as 'logrolling', where favours are traded in order to secure support for particularly important issues, but also happens at the level of individual voters whenever they need to vote in general elections (p. 463). Elections can be understood as multi-issue referenda, where voters are forced to decide which issues are most important to them and choose the party which best represents these. As perfect issue representation does not exist, voters are forced to consider which issues are most vital to them (p.457).

It can be argued that this process is weakened in the UK, as FPTP voting ensures a limited choice of parties (and thus policy sets), and the majoritarian nature of British parliament ensures that political bargaining and compromise seeking are less common. These issues could be resolved in order to translate "the will of the people" more accurately. However, the referendum practice only pushes

\footnotetext{
Marble

14 Research

Papers
} 
these flaws into their most extreme form and is therefore even less capable of communicating what the electorate really wants.

\subsection{Pragmatic legitimacy}

If one assumes that the direct implementation of popular will is able to strengthen democracy, the Brexit referendum's legitimacy still suffers, as it is ultimately not able to translate the electorates preferences. The flawed campaigns, unclear question and poorly defined franchise all result in a referendum which does not translate the preferences of the majority of the British population with regards to leaving the EU. Especially when we take into account the relatively small margin with which the referendum was won.

In addition, the argument can be made that the referendum has an inherent priority problem, where the inability of citizens to communicate the priority of their preferences with regards to other policies, leads to a distortion of their ability to effectively communicate their "will". This could in theory be overcome, but it would require the creation of a different type of referendum, or, a strong parliament which is able to take into account these shortcomings and act accordingly. As neither of these apply to the case of the Brexit referendum, its legitimacy thus suffers in this regard too.

\section{Conclusion}

The referendum is a democratic tool which is, in theory, able to strengthen the redemptive qualities of democracies. However, as this analysis has highlighted, the referendum practice is vulnerable, and its ability to strengthen democratic processes is highly dependent on the circumstances and conduct of the vote. David Cameron's decision to spontaneously call for a referendum, without considering its shortcomings, was thus highly careless. Furthermore, the way in which Theresa May and the British parliament took the legitimacy of the Brexit referendum for granted was misguided. The push for more extensive and intensive political participation is an honourable one. It is also a quest which is able to strengthen democracy. However, the simplicity of organising a popular vote betrays the highly difficult and complex nature of increasing the political power of the individual, and as can be observed in the case of the Brexit referendum, it can unfortunately also backfire.

The Brexit Referendum's democratic legitimacy is compromised on two levels. First, the legitimacy of using popular power to justify leaving the EU is compromised, as the referendum harms both the redemptive and pragmatic faces of democracy. This has caused the referendum to heighten political frustration, without providing any release mechanism for such anger. The Brexit referendum has upset the functioning of democracy, and in doing so, obstructed the fulfilment of both representative and direct democratic ideals. Second, the legitimacy of the Brexit referendum is compromised as it has proven incapable of accurately translating both suggested interpretations of "the will of the people". This inability further decreases democratic legitimacy from a perspective which advocates for the use of popular power.

The untouchable and quasi-holy status which has been awarded to (direct) democracy has led to an unwillingness among politicians, media and citizens alike, to take a more critical approach to the referendum practice. While the real-world implications of organising a Brexit, and the different possible exit strategies are heavily debated, the idea that doing so is necessary as "the people have spoken" is 
regarded as a sacred truth. This tendency is harmful as it disregards the fact that not all referenda are equal, and the possibility of a direct vote being incompatible with the expectations associated with good democratic rule. In conclusion, it can thus be said that although the referendum can be a worthy addition to democracy, it must be able to fulfil certain criteria relating to its use and conduct. The Brexit referendum has unfortunately proven incapable of doing so, and its ability to strengthen the British democratic process is therefore severely compromised. 